\title{
On Chinese Cultural Symbols in The Joy Luck Club
}

\author{
Yongkun Wan \\ Yuxi Teachers College, Yuxi Municipality in Yunnan Province of China 653100 \\ wanyongkun123@163.com
}

\section{Keywords: The Joy Luck Club; Chinese culture; Symbols; Orientalism; Otherness}

\begin{abstract}
In her first and famous novel The Joy Luck Club, Amy Tan, like many other Chinese American writers, creatively employs some striking Chinese cultural symbols to depict the characters, arrange the plots and disclose the development of conflicts. The paper first examines three basic types of Chinese academic comments on the novel, and then makes a summary for such major Chinese cultural symbols used in the novel such as Mahjong, Fengshui, astrology, the Five Elements and the spirit culture. Furthermore, based on Edward W. Said's Oriental theory, the author pays more attention to investigate Orientalism and Anti-orientalism displayed in the novel's text, and finally draw a conclusion that in The Joy Luck Club Amy Tan applies the Orientalist approach to the treatment of Chinese culture so as to attract her white readers, but she also reorganizes these Chinese culture symbols to construct their own Chinese American culture identity, to fight against Orientalism, and to pursue the co-existence of the East and the West.

Amy Tan and her novels are a hot topic for discussion and study both in America and in China. As a highly influential novel, The Joy Luck Club attracts many critics, and comments on this novel are varied and miscellaneous. Looking through Chinese academic studies about The Joy Luck Club, although the research achievements are plentiful, we can find that there are basically three types of comments: The first, high compliment of most critics such as Zhang Ziqing[1], Cui Wansheng[2], Liu Xiaohong[3], Lu Wei[4], Cheng Aimin and Zhang Ruihua[5], is the analysis about cultural theme and content of this novel. The second includes those criticisms on Amy Tan that blame her for distorting Chinese culture to cater western readers' taste, whose representatives are Frank Chin[6], Wang Meng[7], Chen Aimin[8], and Xu Yingguo[9]. The third is the analysis on the using of Chinese cultural symbols in The Joy Luck Club, from which we have Zhang Ruihua[10], Chen Leilei[11], and Huang Shufang[12], etc.
\end{abstract}

\section{Chinese Cultural Symbols in Chinese American Literature}

Many Chinese Americans are deeply rooted in China and the cultural heritage of China has a great latent influence upon them. Before Amy Tan, there are many other Chinese American writers favoring using Chinese cultural symbols in their writings, and maybe using these contents is a convention of Chinese American writers. But, different writers have different purposes in using them and usually get very different effects.

Amy Tan is a representative of the second generation of Chinese immigrants to America. Therefore, her writing of novels, most about the different lives of Chinese Americans, is greatly influenced by Chinese culture which her parents bring to her and American main-stream culture which she gets from her education and her daily life. In The Joy Luck Club, Amy Tan employs various Chinese symbols, which embody the complicated and profound Chinese culture and eastern philosophy, to highlight the cultural conflicts and fusion within and beyond the stories. The Joy Luck Club is really a good model of displaying Chinese culture through a novel, in which such major Chinese cultural symbols as Mahjong, Fengshui, astrology, the Five Elements and the spirit culture are depicted vividly.

Consequently, numerous descriptions of Chinese culture in Chinese American literary works indicate that Chinese American's acceptance of traditional Chinese culture has witnessed a process from the extreme nostalgia of the first generation immigrants to the extreme rejection of the second 
generation immigrants, and finally to a recent convergence[13]. What the Chinese American writers display is not the real, pure Chinese culture, but some Chinese cultural symbols in the eyes of Chinese Americans, that is, the culture of Chinese Americans. Furthermore, what they represent means only a tree compared to the vast and complicated wood of Chinese culture of over 5000 years. There is a difference in the cognitive means of acquiring Chinese culture between native Chinese and Chinese Americans, and the Chinese culture as known by Chinese Americans has undergone a gradual adjustment to the Western environment, so the lack, deconstruction or subversion of the traditional values of Chinese culture in the literary works by Chinese American authors makes Chinese culture appear more as cultural marks than as Chinese culture with all its traditional values[9].

\section{Orientalism in The Joy Luck Club}

Edward W. Said is an internationally renowned American literary and cultural critic, and his masterpiece Orientalism published in 1978 has brought about a shockingly great response all over the world. Orientalism is a great work, which reveals that the West posts its hegemony over the East through placing the East as an inferior Otherness strengthening the West's self-image of superiority. According to Edward W. Said, "The Orient was almost a European invention, and had been since antiquity a place of romance, exotic beings, haunting memories and landscapes, remarkable experiences"[14]. Orientalism can be called a longstanding tradition of the West, on account of which Chinese Americans, as one of the largest minority groups in America, suffered a lot in America and are always regarded as the silent and passive Otherness in American mainstream society. Americans has set up several negative images for Chinese Americans, such as evil Fu Manchu and Dragon Lady, the obedient Charlie Chan and Shy Lotus Blossom.

The influence of Orientalism is so powerful that even Chinese Americans themselves are entangled in it. In order to attract white readers, some Chinese American writers (including Amy Tan) write at great length about interesting people, exotic goods, and amusing customs of China in their works. Living in America, Amy Tan can hardly avoid the influence of Orientalism imposed by the mainstream society. And, Thousands of Westerners are attracted to and satisfied with her depiction of China, the Chinese, and Chinese culture in The Joy Luck Club.

All of Amy Tan's descriptions of the old China in The Joy Luck Club prove that the essence of Orientalism is the ineradicable distinction between Western superiority and Oriental inferiority. The image of China in the novel is past, backward, and chaotic, which forms an antithetical picture with modern America. In Amy Tan's description, the Chinese are tragically oppressed, evil, effeminate, greedy, and difficult to understand. All of these coincide with the Other image of the Oriental held by the white. Taking advantage of her dual identity and placing herself as an informant of Chinese culture, Amy Tan applies the Orientalist approach to the treatment of Chinese culture in The Joy Luck Club. The Chinese in the novel eat rats and dirty innards, cook food in a barbaric way, and believe in superstition like Fengshui, astrology, and the Five Elements, etc. In the novel, besides the recurrent image of food, there are a lot of exotic and eccentric descriptions about Chinese cooking way, and Amy Tan gives her American readers an impression that the Chinese have the tendency to take everything as food. All of these help to create an alien image of Chinese culture. The Chinese are alien in the Westerner's eyes not only for their exotic food culture but also for their ethnic and heathen beliefs, which are labeled as superstitions by the white. Presenting the Chinese as believers of mystic superstitions, Amy Tan details the strangeness of Chinese culture to attract white readers and then wins a great reputation, and again reinforces the Other image of the Chinese and Chinese culture.

Moreover, as stated in Edward W. Said's theory, "It is one of men's weaknesses that they would always rather appeal to a book, a graphic authority, than touch the reality."'[14] Amy Tan is a Chinese American, what she writes is about Chinese, and her all works(including The Joy Luck $\mathrm{Club}$ ) contain autobiographical elements, so her readers certainly consider the novel as a platform to exhibit Chinese culture. Indeed, Amy Tan's The Joy Luck Club not only satisfies and misleads the white readers who know little about China, the Chinese and Chinese culture, but also reinforces the 
negative stereotype about Chinese culture as well as China and the Chinese. With the success of The Joy Luck Club, Amy Tan should be somewhat responsible for her contributions to the formation and confirmation of the stereotyped image popular in the West about Chinese culture.

\section{Anti-orientalism in The Joy Luck Club}

As national minorities, Chinese Americans belong to the weaker group compared with the mainstream American society. Raising demands or fighting for their rights directly can not get the desired result, so they must skillfully earn the chances for living and development. Due to the historical environment and unique cultural identity, Chinese American writers on one hand exaggerate the difference between the Oriental and the Occidental, and highlight the image of Otherness; but on the other hand, they deconstruct Orientalism to some extent to display the significance of equal exchange between the East and the West[15]. Hoping to correct the negative stereotypes of the Chinese, many Chinese American writers like Amy Tan fight against Orientalism with their pens consciously or unconsciously.

In a vivid and fluid style, Amy Tan interweaves the clashes between two cultures, two languages and two generations with humor, fairy-tales, horoscopes, etc. and narrates sixteen wonderful stories shuttling between the past and the present, fiction and non-fiction, east and west[16]. In The Joy Luck Club, Amy Tan takes different attitude to these Chinese cultural symbols according to different needs in developing this novel. Some of these Chinese cultural symbols are the same as the original version in China, such as the Fengshui theory. However, some Chinese cultural symbols are totally changed, such as from Chinese Chang-e's story to the story of Moon Lady. What's more, some other Chinese cultural symbols are partly related to the Chinese version and partly revised, such as the Chinese Taoism philosophy. After analyzing Amy Tan's strategy of using the Chinese cultural components, we can see that she has skillfully combined these contents with her writing, and using them is not just for showing exotic things. She creatively provides a suggestion for the Chinese Americans on how to use the Chinese traditional culture to rebuild their culture identity and to fight against ethnic prejudice in America.

The Chinese, especially Chinese women are the representatives of the silent Oriental in the mainstream American society. Breaking this silence is a way to smash the stereotype of the Chinese American. All of the Chinese women in The Joy Luck Club, including four immigrant Chinese mothers and their America-born daughters, try to walk out of the stereotyped shadow and assert their identities. In addition, Amy Tan's writing and the great achievement her novel gets are breaking this silence of Chinese Americans. Amy Tan tries to challenge these stereotyped Orientalist accounts and negative perceptions of Chinese women by her writing. The four Chinese immigrant women in The Joy Luck Club are all strong-minded mothers and their moving stories challenge the Orientalist characterizations of Chinese American women.

It seems that The Joy Luck Club shares the same opinion with Edward Said that the development and maintenance of every culture require the existence of another, different and competing alter ego[17]. The novel focuses on four pairs of mothers and daughters: Suyuan Woo and Jing-mei Woo, An-mei Hsu and Rose Hsu Jordan, Lindo Jong and Waverly Jong, and Ying-ying St. Clair and Lena St. Clair. The mothers are all Chinese immigrant women who enter the United States after the repeal of the Chinese Exclusion Act in 1943, while the daughters are fully assimilated America-born Chinese. The mother-daughter relationship in this novel has its cultural meaning. Both the mothers and the daughters are products of two cultures. The mothers show their biased nationalism when facing Western society which is totally different from Chinese society. They cut themselves from the outer world and refuse to be assimilated into American mainstream culture. However, the daughters go to another extreme, they regard America as their homeland and completely identify with American culture. In their eyes, Chinese language and customs are the signs of impoverishment and backwardness. All of the mother-daughter pairs in the novel have experienced the misunderstanding, which stems from cultural differences. The mothers' severity and high expectation are expressions of love for and faith in their daughters. However, the daughters always believe that the mothers' constant criticism shows a lack of affection. In addition, the traditional 
Chinese values of filial obedience, criticism-expression of love, and the concealment of excessive emotion all clash with the daughters' American ideas about autonomy, free and open speech, and self-esteem. The misunderstanding existing between mother and daughter not only hurts their relationship but also hurts themselves. In The Joy Luck Club, Amy Tan shows that the opposition of two cultures will result in a lot of pain and suffering. The answer and solution only lies in the conciliation of the two generations and of two cultures. Fortunately, facing the difficulties they meet, the mothers and the daughters stand side by side and finally achieve the integration. The final reconciliation of the mothers and the daughters symbolizes the mosaic of two cultures and illustrates the daughters' final conquering of Orientalism. The mothers and the daughters come to see that China itself contains America aspects, just as the part of America, for example, Chinatown, contains Chinese elements.

Consequently, it can not be denied that Amy Tan's fiction has played a significant role in attracting the attention of the American reading public to Chinese American literature. In The Joy Luck Club, Amy Tan makes a good use of some striking symbols in Chinese culture, and succeeds in depicting the characters, arranging the plots and disclosing the development of conflicts, giving the Westerners an appealing cultural picture of the Chinese American. Thus, the cultural pictures she draws in the novel contribute to its success. She inherits the original meaning of some parts of Chinese traditional culture because they are the good means to keep the ethnicity for Chinese Americans. Amy Tan rewrites some other parts of Chinese culture because this is her strategy to rebel against the stereotypes of Chinese women in the western society, and then establish the new images of Chinese American women. Like other ethnic groups, she should and has to adapt to the dominant culture, but at the same time she has retained her cultural heritage and modified it in accordance with her experiences in America. Her utilizing Chinese culture is also a strategy to construct a new cultural identity for Chinese Americans in the American mainstream culture. Nevertheless, Amy Tan suffers from the pressure from the white dominance in American society, and has no alternative but to try to cater to the white Orientalism. What she depicts in The Joy Luck $C l u b$, is not real China or real Chinese. She projects the image of China as the Other world, the antithesis of America and its civilization. Not only does the novel depict China as backward, chaotic, impoverished and so on, but also presents the Chinese as uncivilized, barbaric and inferior to Americans. In conclusion, Amy Tan embraces both Orirentalism and anti-orientalism behind Chinese cultural symbols of her novel The Joy Luck Club, but it is more important that through the novel she calls for the co-existence of the two worlds, the East and the West, which is coincident with Edward W. Said's good wish.

\section{References}

[1] Z.Q. Zhang: Sina-American Cultural Exchange in Chinese American Literature(In Chinese), Foreign Literature Review. 6(1996)No.3, p.126-134.

[2] W.S. Cui and M. Zhang: A Brief Introduction to and Comment on the Chinese American Writer Amy Tan(In Chinese), Journal of Xuchang Teachers' College. 16(1997)No.2, p.62-65.

[3] X.H. Liu: Lack of Mutual Understanding, Conflicts and Integration: an Examination on the Intercultural Phenomenon behind The Joy Luck Club(In Chinese), Ideology Front. 18(1998)No.9, p.40-45.

[4] W. Lu: The Reconstruction of Subjectivity in The Joy Luck Club as Seen from the Disappearance of Utterances(In Chinese), Journal of Sichuan International Studies University. 16(2000)No.4, p.18-22.

[5] A.M. Cheng and R.H. Zhang: Clashes and Acculturation between Chinese Culture and American Culture: a Cultural Reading behind The Joy Luck Club from the Language and Culture Perspectives(In Chinese), Foreign Literatures. 83(2001)No.4, p.86-92.

[6] F. Chin and J.P. Chan: The Big Aiiieeeee: An Anthology of Chinese-American Literature and Japanese-American Literature(Plume, America 1991), p.1-640.

[7] M. Wang: China and Chinese in Fiction and Cinema(In Chinese), Literature \& Art Studies. 6 (1999)No.3, p.48-49. 
[8] A.M. Chen: On the Presentation of Chinese Culture in the Chinese American Women Literature(In Chinese), Foreign Literature Studies. 12 (2005)No.6, p.71-74, 172.

[9] Y.G. Xu: Chinese Cultural Marks and the Asianization of America(In Chinese), Foreign Literatures. 6 (2006)No.3, p.26-30, 124.

[10]R.H. Zhang: A Cultural Critique of Amy Tan's Novels(In Chinese), Journal of Liaoning Normal University. 24(2001)No.6, p.77-81.

[11]L.L. Chen: Re-reading Amy Tan: Articulation and Deconstruction of the American Mainstream Ideology(In Chinese), Contemporary Foreign Literature. 6(2003)No.3, p.57-61.

[12]S.F. Huang: Chinese Images in The Joy Luck Club and the Cultural Interpretation(In Chinese), Journal of East China University of Science and Technology. 4(2008)No.2, p.103-106.

[13] Y.M. Hu: Nostalgia, Rejection and Convergence: On the Acceptance of Traditional Chinese Culture in Chinese American Literature"(In Chinese), Journal of Sichuan International Studies University. 18(2002)No.5, p.45-48.

[14]W.H. He: Edward Said: the Subversive Intellectual and His Subversion of Orientalism(MS., Central China Normal University, China 2004), p.1-53.

[15]L.P. Zhu: An Analysis of the Orientalism Sense of The Joy Luck Club(In Chinese), Journal of Shaoguan University(Social science). 28(2007)No.4, p.47-50.

[16]X.Y. Xia: Clashes and Acculturation-On the Mother-daughter Relationship in The Joy Luck Club from the Language and Culture Perspectives(MS., Jinan University, China 2001), p.1-55.

[17]E.W. Said: Orientalism(Vintage Books, America 1978), p.1-368. 